\title{
Rumitnya Eksekusi Mati Terhadap Terpidana Mati Narkotika
}

\author{
Ali Johardi \\ Fakultas Hukum, Universitas Bhayangkara Jakarta Raya \\ Email: ali.johardi@dsn.ubharajaya.ac.id
}

Received : 7 Feb 2021 | Revised : 23 Mar 2021 | Accepted : 13 Apr 2021 | Published : 10 Jun 2021

\begin{abstract}
Capital punishment is the heaviest sanction among all types of crimes that exist and is also the oldest, heaviest and is often said to be the most violent and controversial type of crime of all criminal systems, both in countries that adhere to Common Law, as well as in countries that adhere to Civil Law. One of the most important phenomena of capital punishment is the condition of the waiting period. In this condition, the convict is in an uncertain position as he awaits execution. The government basically does not have a definite formula for who will be executed. Seeing the data below, the waiting period of death row inmates varies greatly. Government Policies (Political Will) in the field of law are inadequate due to political influence or international pressure and also because until now Indonesia has not had a comprehensive, integral, Indonesian National Law System in accordance with the character, philosophy, and culture and customs of Indonesia.
\end{abstract}

Keywords: capital punishment, government policy, national law

\begin{abstract}
ABSTRAK
Pidana mati merupakan sanksi yang terberat diantara semua jenis pidana yang ada dan juga merupakan jenis pidana yang tertua, terberat dan sering dikatakan sebagai jenis pidana yang paling kejam dan yang paling kontroversial dari semua sistem pidana, baik di negara-negara yang menganut Common Law, maupun di negara-negara yang menganut Civil Law. Salah satu fenomena paling penting dari pidana mati adalah kondisi masa tunggu. Dalam kondisi ini, terpidana berada di posisi tidak pasti karena menunggu eksekusi mati. Pemerintah pada dasarnya tidak memiliki rumusan yang pasti siapa yang akan dieksekusi, melihat data di bawah ini, maka lama masa tunggu dari terpidana mati sangat bervariasi. Kebijakan Pemerintah (Political Will) di bidang hukum yang belum memadai karena pengaruh politik atau tekanan internasional dan juga karena hingga sampai saat ini Indonesia belum memiliki Sistem Hukum Nasional Indonesia yang komprehensif, integral dan sesuai dengan karakter, falsafah, dan budaya serta adat istiadat Indonesia.
\end{abstract}

Kata Kunci: pidana mati, kebijakan pemerintah, hukum nasional 


\section{PENDAHULUAN}

Salah satu fungsi hukum, adalah membimbing perilaku manusia. Sebagai pedoman ia juga bertugas untuk mengendalikan tingkah laku atau sikap tindak, dan untuk itu ia didukung dengan sanksi negatif yang berupa hukuman agar dapat dipatuhi. Oleh karena itu, hukum juga merupakan salah satu sarana pengendalian sosial. Dalam hal ini, maka hukum adalah suatu sarana pemaksa yang melindungi warga masyarakat dari ancaman-ancaman maupun perbuatan-perbuatan yang membahayakan diri sendiri serta harta bendanya. Jadi, barang siapa yang melanggar hukum, dia akan memperoleh hukuman (pidana). Hukum yang mengatur tentang perbuatan-perbuatan apa yang diancam pidana dan dimana aturan pidana itu menjelma disebut hukum pidana. Oleh karena itu, hukum pidana disebut sebagai Hukum Sanksi Istimewa. Penjatuhan pidana sebagai penderitaan kepada pelanggar hanya merupakan obat terakhir (Ultimum Remedium) yang hanya dijalankan jika usaha-usaha lain seperti pencegahan sudah tidak berjalan. Salah satu bentuk pidana yang paling berat adalah pidana mati.

Pidana mati merupakan sanksi yang terberat diantara semua jenis pidana yang ada dan juga merupakan jenis pidana yang tertua, terberat dan sering dikatakan sebagai jenis pidana yang paling kejam dan yang paling kontroversial dari semua sistem pidana, baik di negara-negara yang menganut Common Law, maupun di negara-negara yang menganut Civil Law. Terdapat dua arus pemikiran utama mengenai pidana mati ini, yaitu: pertama, adalah mereka yang ingin tetap mempertahankannya berdasarkan ketentuan-ketentuan yang berlaku, dan kedua adalah mereka yang menginginkan penghapusan secara keseluruhan. Kecenderungan saat ini adalah penghapusan pidana mati, seperti yang dilakukan beberapa negara Amerika Serikat dan negara-negara Uni Eropa. Indonesia, termasuk negara yang masih mempertahankan pidana mati dalam sistem hukum positifnya. Hal ini terlihat baik dalam Kitab Undang-Undang Hukum Pidana (KUHP).

Indonesia terakhir melakukan eksekusi mati di tahun 2016 terhadap 4 orang terpidana mati, sebelumnya di tahun 2015 Indonesia mengeksekusi 14 orang terpidana mati. Pada 2017, Kejaksaan Agung RI masih tetap berencana melakukan upaya eksekusi mati. Saat ini sedikitnya 165 orang masih masuk dalam daftar tunggu eksekusi mati ${ }^{1}$.

Salah satu fenomena paling penting dari pidana mati adalah kondisi masa tunggu. Dalam kondisi ini, terpidana berada di posisi tidak pasti karena menunggu eksekusi mati. Pemerintah pada dasarnya tidak memiliki rumusan yang pasti siapa yang akan dieksekusi, melihat data di bawah ini, maka lama masa tunggu dari terpidana mati sangat bervariasi. Rentang waktu menunggu sampai 5 tahun dalam Lapas adalah rentang waktu terbanyak, jumlahnya mencapai 87 terpidana mati. Selanjutnya masa tunggu selama 6 sampai dengan 10 tahun dan 11 sampai dengan 15 tahun, jumlahnya mencapai 31 dan 30 terpidana mati. Sepuluh (10) terpidana mati telah menunggu selama 16 sampai dengan 20 tahun di dalam penjara. Menariknya terdapat 2 terpidana mati yang menunggu cukup lama, yaitu 1 (satu) terpidana untuk masa tunggu 21 sampai dengan 25 tahun dan 1 (satu) orang terpidana mati untuk masa tunggu selama 36 sampai dengan 40 tahun.

${ }^{1}$ Data Narapidana Hukuman Mati Seluruh Indonesia, Direktorat Jendral Pemasyarakatan (Ditjenpas) Kementerian Hukum dan HAM, SDP (Sistem Database Pemasyarakatan) tanggal 12 Oktober 2017 
Masa menunggu yang lama ini terjadi karena para terpidana mati mengajukan upaya hukum biasa dan luar biasa yang tidak ada pembatasan waktunya. Hal ini menjadi celah yang dapat dimanfaatkan oleh para terpidana mati untuk mengulur-ulur waktu eksekusi. Sistem hukum Indonesia yang saat ini masih mengadopsi sistem hukum Kolonial Belanda, dirasakan sudah tidak "up to date" dan tidak mampu lagi mengakomodir kejahatan narkotika yang sudah memasuki fase "darurat narkoba", sehingga tidak relevan lagi dengan era globalisasi ini.

Berdasarkan latar belakang tersebut, penundaan eksekusi menimbulkan pertanyaan mengapa terjadi penundaan dan apa yang dapat dilakukan sehingga tidak lagi terjadi penundaan eksekusi mati terhadap para terpidana kasus narkotika. Tujuan penelitian ini adalah untuk mengetahui mengapa terjadinya penundaan eksekusi mati terpidana mati tindak pidana narkotika dan upaya apa sajakah yang dapat dilakukan untuk mengatasi penyebab terjadinya penundaan eksekusi mati terpidana mati tindak pidana narkotika.

\section{METODE PENELITIAN}

Metode penelitian yang digunakan adalah metode penelitian hukum normatif yaitu penelitian yang dilakukan/berfokus pada norma hukum positif berupa peraturan perundang-undangan serta norma-norma hukum yang ada dalam masyarakat. Dalam penelitian hukum normatif data utama yang digunakan berupa data sekunder, meliputi:

a. Bahan Hukum Primer, yaitu bahan-bahan hukum yang berkaitan dengan penundaan eksekusi mati di Indonesia. Dalam penelitian hukum ini, bahan hukum primer terdiri dari:

1) Undang-Undang Dasar Republik Indonesia Tahun 1945;

2) Kitab Undang-Undang Hukum Pidana;

3) Kitab Undang-Undang Hukum Acara Pidana;

4) Undang-Undang Nomor 35 Tahun 2009 tentang Narkotika;

5) Undang-Undang Nomor 2/PNPS/1964 tentang Tata Cara Pelaksanaan Pidana Mati yang dijatuhkan oleh Pengadilan di Lingkungan Peradilan Umum dan Militer;

6) Undang-Undang Nomor 5 Tahun 2010 tentang Perubahan Atas UndangUndang Nomor 22 Tahun 2022 tentang Grasi;

7) Undang-Undang Nomor 1 Tahun 2006 tentang Bantuan Timbal Balik Dalam Masalah Pidana;

8) Undang-Undang Nomor 15 Tahun 2008 tentang Pengesahan Treaty on Mutual Legal Assistance in Criminal Matters (Perjanjian tentang Bantuan Timbal Balik Dalam Masalah Pidana);

9) Peraturan Kepala Kepolisian Negara Republik Indonesia Nomor 12 Tahun 2010 tentang Tata Cara Pelaksanaan Hukum Mati;

10) Surat Edaran Mahkamah Agung Nomor 7 Tahun 2014 tentang Pengajuan Permohonan Peninjauan Kembali Dalam Perkara Pidana. 
b. Bahan Hukum Sekunder, yaitu bahan hukum yang tidak mempunyai kekuatan hukum mengikat secara yuridis seperti buku literatur, pendapat hukum, majalah, jurnal, hasil laporan penelitian, makalah penelitian, dan dari website yang berhubungan dengan penundaan eksekusi mati.

c. Bahan Hukum Tersier, yaitu bahan hukum yang memberikan petunjuk maupun penjelasan terhadap bahan hukum primer dan bahan hukum sekunder seperti Kamus yang berhubungan dengan penelitian ini yaitu Kamus Besar Bahasa Indonesia.

Teknik pengumpulan dan pengelolaan data dalam penelitian ini dikelompokkan dalam dua bentuk, yaitu:

a. Studi Kepustakaan, yaitu dengan mempelajari Bahan Hukum Primer dan Sekunder.

b. Wawancara dengan narasumber, yaitu melakukan wawancara dengan narasumber yang bersangkutan mengenai data yang akan mendukung penelitian, yaitu Narasumber dari Mahkamah Agung, Kejaksaan Agung, Lapas Narkotika dan Badan Narkotika Nasional. Selain itu, wawancara juga akan dilakukan terhadap beberapa pakar pidana.

Analisis data dilakukan dengan cara menganalisis bahan hukum primer, yaitu deskripsi hukum positif, sistematis hukum positif, analisis hukum positif, interpretasi hukum positif, dan menilai hukum positif, serta menganalisis bahan hukum sekunder berupa data yang diperoleh dari narasumber. Setelah itu dengan pemikiran logis dan sistematis akan ditaris suatu kesimpulan dengan menggunakan metode berpikir deduktif, yaitu pengambilan kesimpulan dimulai dari pernyataan atau fakta-fakta umum menuju kesimpulan yang bersifat khusus.

\section{PEMBAHASAN}

\section{Pro dan Kontra Hukuman Mati}

Secara umum pandangan Hukum terhadap masalah penundaan pelaksanaan hukuman mati termasuk terhadap terpidana mati Narkoba yang sudah berkekuatan hukum yang tetap, adalah timbulnya dua pandangan Hukum di dalam masyarakat, yaitu masyarakat yang setuju atas pelaksanaan hukuman mati bagi terpidana Narkotika karena akibat perbuatannya dapat menimbulkan kerusakan dan kerugian yang sangat masif baik terhadap jiwa, harta benda, kehidupan sosial, maupun ketahanan Negara dan bangsa Indonesia. Hukuman mati juga dapat berfungsi sebagai deterrent effect yang dapat menimbulkan efek jera untuk mereka yang belum melakukan tindak pidana.

Pandangan yang kedua, adalah masyarakat yang tidak setuju atas pelaksanaan hukuman mati atas dasar pertimbangan Hak Asasi Manusia (HAM). Menurut mereka, tujuan penghukuman untuk memberi dampak jera dan pembalasan atas perbuatan pelaku kejahatan Narkoba yang membawa dampak kerusakan yang besar, terbukti tidak mencapai tujuannya dan tidak memberi efek jera, karena kejahatan Narkoba sampai saat ini masih terus terjadi dan semakin meningkat dengan modus operandi yang semakin canggih.

Sayangnya, pandangan masyarakat tentang hukuman mati ini, hanya terbagi atas dua kubu saja, yaitu yang setuju dan mendukung hukuman mati dan yang menghendaki penghapusan hukuman mati (Abolishment), dan tidak ada lagi alternatif pilihan pandangan lain selain dua kubu diatas. 


\section{Pengaruh Kebijakan Politik terhadap Dinamika Sistem Peradilan Pidana yang Berlaku di Indonesia}

Pandangan dalam konteks hukum di Indonesia, bahwa ketidakpastian pelaksanaan hukuman mati bagi terpidana Narkoba, dipengaruhi oleh faktor dinamika sistem peradilan pidana yang berlaku di Indonesia. (adanya ketidakpercayaan mahkamah konstitusi terhadap sistem peradilan pidana (jaksa, penegak hukum, dll) sehingga dapat dikatakan sistem hukum di negara ini sudah tidak normal. Putusan hukum tidak lagi dilihat sebagai upaya hukum murni, karena telah dipengaruhi politik.

Terkait dengan sistem peradilan pidana yang berlaku di Indonesia, Hukum Acara Pidana sebagai Prosedur yang harus dipenuhi dalam melaksanakan eksekusi. Ada beberapa tahapan hak hukum yang dimiliki oleh seorang terpidana mulai dari Banding, Kasasi, PK hingga grasi. Sebagai negara yang memiliki sistem hukum, semua stakeholder terkait harus dapat menghormatinya. Dalam lingkup pergaulan internasional, beberapa negara seperti Perancis, Brazil dan China secara terangterangan menyoroti praktik hukuman mati yang dilaksanakan oleh Indonesia terhadap warga negaranya, sehingga Indonesia harus berhati-hati dalam pelaksanaannya. Kembali lagi ke politik, diperlukan ketegasan politik bangsa ini untuk menunjukkan kedaulatannya.

Selain hak hukum terpidana mati, ada juga beberapa regulasi yang membuat pelaksanaan eksekusi mati menjadi terhambat, seperti contoh adanya Undang-Undang No. 5 Tahun 2010 tentang Grasi disusul dengan terbitnya putusan MK Nomor 107/PUU-XIII/2015. Eksekusi putusan pengadilan yang berkekuatan hukum tetap dalam perkara pidana menjadi tugas dan kewenangan Jaksa pada Kejaksaan Republik Indonesia, seperti yang diamanatkan KUHAP dan Undang-Undang No. 16 Tahun 2004 tentang Kejaksaan. Pelaksanaan tugas dan kewenangan mengeksekusi putusan kerap mendapat perhatian masyarakat, terlebih-lebih berkenaan dengan eksekusi mati. Kontroversi berkenaan pidana mati rupanya melebah hingga eksekusinya, dan bukan semata-mata dalam ranah legislative and judicatice policy. ${ }^{2}$

\section{Fungsi Jaksa dalam Proses Eksekusi}

Dalam sistem peradilan pidana Indonesia, pelaksanaan putusan pengadilan yang telah berkekuatan hukum tetap, sepenuhnya menjadi kewenangan Jaksa pada Kejaksaan Republik Indonesia. Tidak termasuk eksekutor adalah Jaksa pada KPK, karena Undang-Undang No. 30 tahun 2002 tentang KPK, tidak memberikan kewenangan kepada lembaga itu, termasuk pejabat/pegawainya, untuk melakukan eksekusi putusan. Kewenangan mengeksekusi putusan yang telah berkekuatan hukum tetap secara atributif ditegaskan dalam KUHAP menjadi monopoli Jaksa pada Kejaksaan, karena tidak ada pejabat lain, termasuk aparatur sistem peradilan pidana lainnya yang diberi wewenang sama. Hal ini tercermin dari beberapa ketentuan yang mengatur tentang kewenangan Jaksa dalam melaksanakan putusan pengadilan, antara lain:

1) Pasal 1 angka 6 huruf a KUHAP yang menentukan bahwa Jaksa adalah pejabat yang diberi wewenang oleh undang-undang ini untuk bertindak sebagai penutut umum serta melaksanakan putusan pengadilan yang telah memperoleh kekuatan hukum tetap;

2 https://fh.umj.ac.id/eksekusi-pidana-mati-pasca-putusan-mahkamah-konstitusi-nomor107puu-xiii2015/Dr. Chairul Huda, S.H, M.H 
2) Pasal 270 KUHAP yang menentukan bahwa pelaksanaan putusan pengadilan yang telah memperoleh kekuatan hukum tetap dilakukan oleh Jaksa, yang untuk itu panitera mengirimkan salinan surat putusan kepadanya.

Kewenangan mengeksekusi putusan yang telah berkekuatan hukum tetap yang diberikan oleh KUHAP kepada Jaksa, kemudian diejawantahkan lebih lanjut dalam Undang-Undang No. 16 Tahun 2004 tentang Kejaksaan. Dalam hal ini per definisi "jaksa" adalah pejabat fungsional yang diberi wewenang oleh undang-undang untuk bertindak sebagai penuntut umum dan pelaksana putusan pengadilan yang telah memperoleh kekuatan hukum tetap serta wewenang lain berdasarkan undang-undang (Pasal 1 angka 1 UU No. 16 Tahun 2004). Dalam Pasal 30 ayat (1) huruf b UU No. 16 Tahun 2004 tentang Kejaksaan, Jaksa "melaksanakan penetapan hakim dan putusan pengadilan yang telah memperoleh kekuatan hukum tetap" menjadi tugas dan wewenang kejaksaan di bidang pidana.

Berdasarkan hal itu, pelaksanaan putusan pengadilan yang telah berkekuatan hukum tetap menjadi wewenang Jaksa dan Kejaksaan, yang pada dasarnya bersifat "subordinated" dari kekuasaan kehakiman. Namun demikian, bukan berarti tidak ada sama sekali ruang diskresional berkenaan dengan hal ini, mengingat Jaksa dalam melaksanakan tugas dan wewenang harus mengindahkan norma-norma keagamaaan, kesopanan dan kesusilaan serta wajib menggali dan menjunjung nilainilai kemanusiaan yang hidup dalam masyarakat, sebagaimana ditegaskan dalam Pasal 8 ayat (4) UU No. 16 Tahun 2004 tentang Kejaksaan. Demikian pula halnya, dalam melaksanakan tugas dan wewenang mengendalikan pelaksanaan pidana mati.

Menurut Jampidum, secara teknis Jaksa tidak bisa melakukan eksekusi walaupun terpidana sudah melampaui batas waktu untuk melakukan upaya hukum. Namun secara yuridis sepanjang terpidana sudah menggunakan seluruh hak hukumnya, maka eksekusi dapat segera dilaksanakan. Terkait dengan fungsi Jaksa, dalam sistem peradilan pidana, yang menjalankan putusan pengadilan adalah jaksa penuntut umum. Apabila belum ada keputusan eksekusi dari jaksa penuntut umum, dalam hal ini Kejaksaan Agung, maka eksekusi tersebut belum bisa dilaksanakan.

Selaku eksekutor pelaksana hukuman terhadap vonis pengadilan yang telah berkekuatan hukum tetap, Jaksa selaku Penuntut Umum dan eksekutor putusan melaksanakan tugas sesuai ketentuan peraturan perundang undangan. Termasuk eksekusi putusan terhadap terpidana mati kasus kejahatan Narkotika. Mengenai waktu pelaksanaan eksekusi yang tidak menentu khususnya terhadap terpidana mati kasus Narkotika, Jaksa sebagai eksekutor disamping melaksanakan sesuai ketentuan Undang Undang, juga harus mempertimbangkan secara hati hati dan cermat, mengingat pidana mati sangat sensitif dengan HAM dan jika telah dilakukan eksekusi terhadap terpidana, maka jika timbul persoalan setelah eksekusi, terpidana tidak dapat diminta keterangan atau pertanggung jawaban lagi.

Di samping itu Jaksa selaku eksekutor putusan pidana mati, juga adalah aparatur Pemerintah di bidang Penegakkan hukum, maka segala tindakan yang dilakukan termasuk mengeksekusi mati terpidana kasus Narkotika, harus mempertimbangkan dan memperhatikan Kebijakan Pemerintah. Apalagi yang menjadi terpidana mati kasus Narkotika terdiri dari berbagai bangsa/ kewarganegaraan. 


\section{KESIMPULAN}

Berdasarkan data hasil penelitian yang telah dianalisis dapat disimpulkan hal-hal sebagai berikut:

1. Penundaan eksekusi mati terhadap terpidana mati kasus narkotika karena ada peluang upaya hukum yang tanpa batas dan tidak ada peraturan yang khusus mengatur batasan waktu pelaksanaan eksekusi mati. Hal ini menimbulkan rasa "ketidakpercayaan" antar Lembaga peradilan. Keputusan Mahkamah Konstitusi No. 34/PUU-XI/2013 dan SEMA No. 7 Tahun 2014, yang saling bertentangan dan bertolak belakang juga merupakan salah satu bentuk ketidakpastian sistem pidana di negeri ini dan juga merupakan celah hukum bagi terpidana untuk mengajukan upaya hukum yang tidak terbatas sehingga berdampak penundaan eksekusi mati yang tanpa batas, yang akibatnya terpidana menjalani dua pemidanaan yaitu pidana penjara dan pidana mati.

2. Kebijakan Pemerintah (Political Will) di bidang hukum yang belum memadai karena pengaruh politik atau tekanan internasional dan juga karena hingga sampai saat ini Indonesia belum memiliki Sistem Hukum Nasional Indonesia yang komprehensif, integral dan sesuai dengan karakter, falsafah, dan budaya serta adat istiadat Indonesia. Hal ini menimbulkan kontroversi pelaksanaan hukuman mati di Indonesia, sehingga terjadi penundaan tanpa batas, khususnya terhadap terpidana mati kasus narkotika karena mereka telah melanggar HAM dan menyebabkan kematian sia-sia jutaan jiwa generasi muda Indonesia setiap tahunnya. Di samping itu, kebijakan ini layaknya teori 'bandul jam' sehingga menimbulkan pro kontra di masyarakat dan tidak sesuai dgn tujuan hukum yaitu KEPASTIAN HUKUM dan KEADILAN.

3. Belum optimalnya peran Jaksa Penuntut Umum sebagai eksekutor hukuman mati, karena dua hal sebagaimana di atas (upaya hukum dan political will), hal ini membuat eksekutor bimbang karena belum ada aturan baku yg mengatur, cenderung menunggu instruksi dari 'atas' dan khawatir dianggap melakukan pelanggaran HAM. Padahal hukuman mati berdasarkan peraturan per undangundangan di Indonesia dibenarkan dan termasuk hukuman pokok dan Jaksa aparatur negara di bidang penegakan hukum, seharusnya melaksanakan tupoksi(eksekutor) dengan baik, bukan mengambil sikap 'sendiri'.

\section{SARAN}

Berdasarkan paparan tersebut di atas, penulis dapat mengemukakan saran sebagai berikut:

1. Kebijakan Pemerintah untuk membentuk Tim Penyusun Sistem Hukum Nasional yang dikoordinir oleh Kementerian Hukum dan HAM RI melalui Badan Pembinaan Hukum Nasional (BPHN).

2. Menyusun Peraturan perundangan-undangan yang mengatur khususnya tentang mekanisme, tahapan, dan Batasan waktu upaya hukum luar biasa bagi terpidana mati kasus narkotika.

3. Memperjuangkan revisi Undang-Undang Narkotika dengan tetap memasukkan sanksi hukuman mati.

4. RUU KUHP agar tetap memasukkan hukuman mati sebagai hukuman pokok. 


\section{DAFTAR PUSTAKA}

\section{Buku}

H Siswanto S, 2012, Politik Hukum Dalam Undang-Undang Narkotika (UndangUndang Nomor 35 Tahun 2009), Cetakan Pertama, PT Rineka Cipta, Jakarta.

Aruan Sakidjo dan Bambang Poernomo, 1990, Hukum Pidana: Dasar Aturan Umum

Hukum Pidana Kodifikasi, Cetakan Pertama, Ghalia Indonesia, Jakarta.

Moeljatno, 2008, KUHP: Kitab Undang-Undang Hukum Pidana, Cetakan 27, PT Bumi Aksara, Jakarta.

\section{Website}

https://fh.umj.ac.id/eksekusi-pidana-mati-pasca-putusan-mahkamah-konstitusinomor-107puu-xiii2015/Dr. Chairul Huda, S.H, M.H. 